DOI: https://doi.org/10.46630/phm.12.2020.31

Petra V. Mitić ${ }^{1}$

Univerzitet u Nišu

Filozofski fakultet

Centar za strane jezike
Pregledni rad

УДК 821.14'02.09-2 Eshil 821.11(73).09-2 O'Nil J.

801.73

Primljen: 5. 10. 2019.

\title{
ESHILOVA ORESTIJA IZ VIZURE FEMINISTIČKE KRITIKE: OD OSUDE DO DRUGAČIJEG ČITANJA²
}

Do koje mere tekst Orestije još uvek predstavlja kritički izazov pokazuje i kontroverza koja je nastala nakon pokušaja američkog nobelovca Judžina O'Nila da u čuvenoj drami Crnina Pristaje Elektri ponudi savremeno „čitanje” ovog kapitalnog teksta zapadne književnosti. Polemiku koja je usledila nakon što su kritičari upotrebili „edipovski obrazac” kao jedinu ispravnu vizuru iz koje bi trebalo tumačiti značenje drame, i pokušaj samog O'Nila da se „odbrani” od takvog modela interpretacije, uzećemo kao polazište u ovom radu, sa ciljem da razmotrimo koji su potencijali Eshilove drame ostali skrajnuti u tradicionalnom modelu tumačenja. Problem se dodatno usložnjava time što su u kontekstu ove polemike postali jasno uočljivi i nedostaci ortodoksne feminističke analize, koja je u ovom slučaju krenula, naravno, od suprotnog vrednosnog predznaka u odnosu na opšteprihvaćeni patrijarhalni model, ali je u konačnom ishodu samo ponovila identičan interpretativni obrazac. Na ovaj način je i ova radikalna kritička škola, koja je trebalo da ponudi značajan iskorak iz domena tradicionalne hermeneutike, ostala „slepa” za sve one subverzivne aspekte značenja na koje će s pravom ukazati kritičari poput Seli Geč ili Filipa Velakota.

Ključne reči: Orestija, Judžin O’Nil, patrijarhalni model čitanja, feministička kritika i interpretacija, dekonstrukcija i „,ponovno čitanje”.

\section{Uvod}

„Revizija - kao pogled unazad, posmatranje drugačijim očima, i kao ulazak u stari tekst iz nove kritičke pozicije - predstavlja za nas više od tek jednog poglavlja kulturne istorije: ona predstavlja čin opstanka" (nav. u DONOVAN 1975:74). Ovim značajnim rečima američka pesnikinja Adrijen Rič

\footnotetext{
${ }^{1}$ petra.mitic@filfak.ni.ac.rs

${ }^{2}$ Rad je prezentovan na međunarodnom Simpozijumu Antička drama na Filološkom fakultetu u Beogradu oktobra 2016. godine.
} 
[Adrienne Rich] formulisala je imperativni zadatak savremenog pisca i kritičara, a ujedno i na najsažetiji način sumirala kritičko polazište pravca koji danas znamo pod nazivom feminizam. Na tragu ideje koja pokušava da predoči mogućnost i viziju postpatrijarhalne stvarnosti, Amber Džejkobs [Amber Jacobs], feministička teoretičarka novije generacije, upućuje nas na samo izvorište zapadne kulturne paradigme, koja je svoj prvi simbolički prikaz dobila u antičkom mitu o Orestu i ubistvu majke. Ona ukazuje da je reinterpretacija mita i njegovog umetničkog uobličenja u dramama antičkih tragičara važna feministička strategija koja bi trebalo da u samom ishodištu kulture prepozna na koji način je jedna fantazija o moći dovela do utemeljenja patrijarhalne stvarnosti - kao zakona koji nema alternativu (DŽEJKOBS, 2007). Pritom, Džejkobs se poziva na ideje belgijske feministkinje, Lis Irigarej [Luce Irigaray], koja je u tekstu „Telesni susret s majkom” (1995) istakla kako naše imaginarno još uvek sledi obrazac koji je uspostavila grčka tragedija - ono što nam opisuje Orestija i danas se, nakon svih feminističkih pobeda, iznova odigrava. Mitološki obrazac odražava suštinu poretka u kome se pod simboličnom vlašću boginje Atene pobunjenička snaga Furija preusmerava - strateški lukavo - u službu novom poretku polisa, koji sada postaje poredak bez alternative.

Pozivajući se na reči iz teksta Lis Irigarej, Džejkobs objašnjava da je patrijarhalni simbolički poredak zapravo proizvod specifičnog sistema imaginacije, nastao projekcijom nesvesnih fantazija koje su kroz podršku društvenih institucija dobile snagu zakona: „Simbolički poredak je imaginarni poredak koji je postao zakon" (nav. u DŽEJKOBS 2007: 18). Zbog toga je veoma važno da se kroz analizu mitskih metafora vratimo na same početke kulture jer su upravo u njima zabeležene prvobitne kulturne predstave koje, kasnije, kroz strukturne mehanizme simboličkog delovanja stiču oreol apsoluta i kulturnih determinanti. Feminističko čitanje mita i tragedije je, dakle, deo strategije koja ima za cilj da identifikuje i kritički ispita fantazije koje konstituišu „pobednički imaginarni sistem". Ovo čitanje nosi jasno artikulisan zahtev da se iz perspektive sadašnjosti i savremene kulture suočimo sa fantazijama koje čine dubinsku matricu kulture, i koje su kao takve unapred determinisale sadržaje i oblike društvene i političke realnosti. Time se njihov status apsolutnih istina razotkriva kao lažna slika njihove prave utemeljenosti u imaginarnom sistemu koji je dobio tretman neprikosnovene realnosti.

\section{Moderna Orestija u umetničkoj vizuri Judžina O’Nila}

Iako je svoju čuvenu trilogiju Judžin O’Nil napisao skoro čitav vek ranije, moglo bi se reći da je američki nobelovac imao nameru gotovu identičnu 
nastojanjima pomenutih feminističkih teoretičarki. U intervjuu pod naslovom „Šta je za mene pozorište”, koji je dao daleke 1922. godine, Judžin O'Nil izgovara reči koje i danas snažno odjekuju: „Pozorište je za mene život - suština i interpretacija života ... a život je borba, i to najčešće neuspešna; zato što većina nas nosi nešto u sebi što ga sprečava da ostvari ono što želi i ono što sanja"’3. Ove reči, koje ni posle skoro celog veka nisu izgubile na aktuelnosti, tiču se suštine umetničkog izraza i uloge pisca u društvu, za koga je O’Nil smatrao da ukoliko stremi ka tome da postane nešto više od pukog „salonskog zabavljača”, on mora da zagrebe duboko ispod površine stvari do samih korena tog nečeg što predstavlja uzrok bolesti i životnog neuspeha. U sklopu ovakve definicije pozorišta i sopstvene uloge kao dramskog pisca, veoma je značajno što je za svoj najambicioznije zamišljen dramski tekst - trilogiju Crnina Pristaje Elektri (Mourning Becomes Electra), koju u jednom pismu naziva svojom ,psihološkom dramom žudnje” - O'Nil odabrao upravo mitski okvir Eshilove Orestije, i u kontekst antičkog mita, kao i Eshilove umetničke obrade, postavio sopstvenu porodičnu dramu. Smeštena u vreme američkog građanskog rata, ona se sada u jednoj izmeštenoj vizuri, ali kroz dramaturški veoma efektno izvedenu paralelu, uspostavlja kao pandan dešavanju iz naizgled nesamerivo drugačijeg vremena i prostora. Postavljanjem u kontekst mita onoga što se dešava junacima njegove dramske priče, O'Nil je u fokus postavio ne samo sopstveno čitanje samog mita već i celokupnog kulturnog konteksta u kome je takav mit nastao i na koji se on odnosi. Izmeštanjem porodične drame, kao i celokupnog tematskog okvira Orestije, u vremensku ravan američkog građanskog rata, O’Nil je pre svega ukazao na izvanrednu aktuelnost mitske metafore ili, preciznije, na neophodnost sagledavanja i vrednovanja sadašnjosti upravo kroz prizmu mitske priče o sukobu dva principa i trijumfalnoj pobedi jednog - patrijarhalnog principa Oca i Logosa.

Modernost sopstvenog teksta koju je pisac pri tom imao na umu ostvaruje se u ravni implicitne jukstapozicije - sadašnjost je, sugeriše O'Nil, neophodno sagledati kroz prizmu prošlosti, ili kroz odnos sadašnjosti naspram prošlosti, koji autor doživljava kao fatalno učešće i delovanje prošlosti na sadašnjost. Ovaj odnos ostvaruje se istovremeno u dve paralelne ravni, kao dve različite sadašnjosti koje obe bivaju postavljene i vrednovane u sklopu šireg istorijskog i mitskog okvira - sadašnjosti u smislu vremena iz kojeg piše O'Nil, ali i sadašnjosti iz pozicije njegovih dramskih likova. Sukob principa oca i principa majke, i pobeda prvog, kao tematski okvir Eshilove drame, u O’Nilovom postupku postaje narativna matrica njegovog ličnog viđenja modernosti. Kroz autorov umetnički prosede, on jasno zadobija status tragičnog ishodišta svemu onome što se kao naizgled neumoljiva ruka sudbine obrušuje

${ }^{3}$ Prevedeno iz januarskog broja časopisa Century Magazine (1922), a integralni tekst intervjua može se naći u knjizi Oliver M. Sayler, Our American Theatre (Brentano, 1923). 
na junake O’Nilove drame. Ono što se dešava protagonistima ove moderne Orestije O'Nilov dramski postupak predstavlja, naime, kao tragični finale čuvenog fatalnog izbora kojim se završava Eshilova tragedija.

\subsection{Kritička recepcija O’Nila i pokušaj pisca da odbrani sopstveni tekst}

O’Nilovu vizuru su pojedini kritičari pokušali da okarakterišu kao izraz fatalnog pesimizma mračnog Irca, koji sopstveni mrak projektuje kao umetničku istinu. To je, među prvima, učinio jedan od najuglednijih britanskih književnih kritičara (DEJČIZ, 1961) u tekstu naizgled duhovitog, a zapravo tendencioznog naslova („Crnina pristaje O’Nilu”) kojim se upravo izokreće ideja vodilja i razlog nastanka O’Nilove moderne Orestije. Sa svoje strane, Dejčiz ne poriče ideju generacijske zle kobi, koja se u O'Nilovom umetničkom postupku nameće kao katalizator dramske radnje, ali je u konačnoj analizi tumači jedino kao projekciju autorove lične tragedije. Iz jedne drugačije kritičke vizure, bespomoćnost O’Nilovih junaka nosi daleko ozbiljniju i višestruku simboliku i izrasta u mnogo više od pukog izraza fatalnog pesimizma ili lične projekcije. Njihova nemoć da se odupru silama destrukcije u sebi i oko sebe, koje niti razumeju niti mogu da kontrolišu, čita se kao moćna optužba koju O'Nil upućuje svom vremenu i sopstvenoj kulturi. Ako O'Nilu pristupimo sa ovog stanovišta, onda potpuni mrak kojim se njegova drama završava - kada njegova moderna Elektra u samoj završnici zahteva da se zakucaju prozorski kapci kako sunce više ne bi moglo da uđe unutra - izrasta u umetnički moćnu metaforu bolesti sadašnjosti (the sickness of today), kakvu je autor imao na umu, a koju sam izričito i spominje u jednom pismu ${ }^{4}$. Potpuni mrak ostaje zaista kao simbolički znak za jedini prikladan prostor u kome moderna Elektra ostaje da živi, zato što u njemu prepoznaje svoju konačnu sudbinu, i jedino primerenu kaznu za sopstveno učešće u majčinoj smrti. Ona se povlači u mrak svoje svojevrsne kuće mržnje kao u svoje konačno utočište, zatvor iz koga više nema izlaza, što je ujedno i završna scena trilogije. Kao takva, ova završna scena predstavlja ironičan pandan raskošnoj povorci koja slavi novi poredak i navodni trijumf razuma sa kraja Eshilove tragedije.

O’Nilova odluka da kao svoj najambicioznije zamišljen dramaturški poduhvat napiše modernu Orestiju zasniva se upravo na spoznaji da se čitanjem Eshila na način na koji to čini tradicionalna kritika potpuno gubi ironični smisao njegove metafore. Izbor koji zvanično ustoličuje Atena, grčka boginja mudrosti, O'Nilovo čitanje prepoznaje kao fatalni zametak ,,porodičnog prokletstva" tj. one mržnje Menonovih predaka pred kojom će, kao pred neu-

\footnotetext{
${ }^{4}$ U pitanju je pismo koje navodi Džozef Krač [Joseph Wood Krutch] u uvodu svog izdanja O’Nilovih drama. Vidi Eleanor Flexner, American Playwrights: 1918-1938 (NewYork, 1966), p.133.
} 
moljivom rukom sudbine, junaci njegove tragedije ostati potpuno nemoćni. Moderna psihološka drama koju je želeo da napiše morala je zato da bude umetnički uobličena tako da u prvi plan istakne neophodnost viđenja grčkih bogova kao pesničkih metafora, a grčki fatum, ili sudbinu, prikaže kao delovanje prošlosti na sadašnjost. Sudbina, u O’Nilovoj umetničkoj viziji, proizilazi iz same porodične prošlosti u smislu nasleđenih obrazaca, ili modela postojanja kojima ljudska porodica unapred žrtvuje sopstveno potomstvo. Jedan od efektno odabranih detalja koji podupiru ovako koncipirano umetnikovo čitanje Eshila čine i sablasni portreti predaka na zidovima porodične kuće, koji sugerišu bezizlaz, klopku, utamničenje i predodređenost. Bolest porodice Menon ne dolazi spolja, drugim rečima - porodica je bolesna iznutra, njeni su preci podigli zidove mržnje i negacije, i postali zatočenici vlastitog straha, ili vlastitih zidova.

Čovek je bolestan, sugeriše O’Nil, zato što je svoje postojanje zasnovao na negaciji totaliteta vlastitog bića - on je postao Man non - a svoju kulturu kao svoju kuću, ili svoju ,udobnu metafizičku vilu” kako je to Haksli [Aldous Huxley] efektno opisao u jednom od svojih tekstova (,Wordsworth in the Tropics”), pretvorio time u sopstvenu tamnicu. Za ,tragičnu mehaničku lutku”, kako O'Nil naziva svoju modernu Elektru, ne postoji mogućnost izbora budući da je on učinjen mnogo ranije, a njen jedini iskorak iz nasleđenog modela sastoji se u saznanju da su sva vrata već zatvorena i da izbora - zapravo nema. Za Laviniju ne postoji mogućnost da izabere put ljubavi zato što su „mrtvi previše jaki" i zato što je njihova mržnja postala deo nje same, a sablasna kuća Menonovih - klopka iz koje nema izlaza. Iz perspektive ovako zacrtane budućnosti kao jedinog izbora, koji to nikako nije, a zapravo jedino primerene kazne za sopstveno učešće u događajima koji su kulminirali potpunom dezintegracijom porodice, završni pozdrav koji upućuje boginja Atena, sa poslednje stranice Eshilove tragedije, dobija pečat vrhunske ironije: „I devojke i žene, buljuk starica - / u skerletnome ruhu nek se poređa / i boginjama moćnim Eumenidama / to ime im je sada - neka poštu odaje! / Sad pođite, i lučev neka svetli plam, / da ta mi družba zemlji bude odana / i svagda stvara silne, slavne građane!" (ĐURIĆ 1994: 589).

U kritičkim prikazima O’Nilove drame nije se, međutim, polazilo ovim putem, već je pažnja većine kritičara bila usmerena na to da se ukaže na navodno postojanje frojdovske simbolike u O’Nilovom dramskom postupku, tj. da je Frojdova teorija libida jedina prava pozadina iz koje se njegovi likovi i dramska radnja mogu razumeti. Začuđujućom brzinom i neobjašnjivo lakonski, O’Nil će biti okarakterisan kao „frojdovac”, za koga je osujećeni seksualni impuls glavni uzrok svekolikog zla. „Ono što čudi je, međutim, to da je samo jednom uspeo da na tome izgradi zaista dobar dramski komad - svoju dramu Crnina Pristaje Elektri ", cinično će prokomentarisati Elenor Fleksner [Eleanor Flexner], jedna 
od mnogih koji su pisali o Judžinu O’Nilu. Jer sam autor je ogorčeno poricao uticaj Frojdove psihoanalize i priznavao u smislu izvesnog uticaja jedino Junga, ali veliki broj kritičara ostao je pri mišljenju da se njegove drame, a pre svih ostalih njegova moderna Orestija, mogu najbolje razumeti upravo iz perspektive Frojdovih ideja, što je išlo do te mere da mu je upućena zamerka kako je u tome ponekad čak i preterivao5. Iz vizure feminističke revizije o kojoj piše Adrijen Rič, ovakvo tumačenje predstavlja u izvesnom smislu odbijanje da se vidi sve ono drugo što se opire ovako usko shvaćenoj, ili čak u potpunosti pogrešnoj interpretaciji, i proglašavanje ovog čina negacije, ili represije, legitimnim činom tumačenja. Videti u O'Nilu frojdovca podrazumeva i odbijanje da se čuju sva ona umetnički dovoljno snažno nagoveštena pitanja koja antički mit šalje kroz vekove, ali koja mi ne možemo da čujemo zato što smo, kao što ističe Erih From, zaboravili jezik svojih dubina - univerzalni jezik simbola i sopstvenih snova. ${ }^{6}$

\section{Eshilova Orestija - paradoks feminističke kritike i neophodnost drugačijeg čitanja}

U kontekstu „sudbine” koja je zadesila O'Nilovu modernu Orestiju, a koja je ovde ukratko predstavljena, manje bi trebalo da iznenađuje to što je i u slučaju Eshila feministička kritika uglavnom ponovila obrazac tradicionalnog modela koji antičkog tragičara tumači iz patrijarhalne vizure. Paradoks ove situacije sastoji se u tome što je sama feministička kritika, kao radikalna kritička škola, ovaj model ne samo deklarativno poricala, već i najžešće napadala. Pa ipak, u ranim tumačenjima zapadnog književnog kanona, feminizam je uglavnom ostajao bez snage da prepozna tragove tog istog patrijarhalnog modela u sopstvenoj strategiji čitanja. Jer kako inače objasniti zapanjujuću činjenicu, na koju ukazuje američka teoretičarka Seli Geč [Sallie Goetsch], da u periodu od preko dva milenijuma gotovo nikom nije palo na pamet da posumnja $\mathrm{u}$ tradicionalnu definiciju Eshila kao konzervativnog, patriotskog, religioznog i militaristički nastrojenog pesnika, i to uprkos tome što sami njegovi tekstovi ne pružaju uporište ovakvoj karakterizaciji (GEČ 1994: 75). Kako ističe i britanski teoretičar drame Filip Velakot [Philip Vellacott], ironična dimenzija Eshila nije se, sve do poslednjih decenija dvadesetog veka, a i tada samo sporadično, uopšte uzimala u obzir kao mogućnost čitanja (VELAKOT 1991:4).

Za razliku od tradicionalnog modela čitanja, feministička kritika je kao svoje polazište u odnosu na patrijarhat i njegove apologije imala, naravno,

\footnotetext{
${ }^{5}$ Travis Bogard citira ogorčeni odgovor koji je O’Nil uputio kritičaru koji mu je zamerio zbog navodno previše eksplicitne upotrebe Frojdovih ideja u trilogiji (BOGARD 1972: 345).

${ }^{6}$ Detaljnjije o Fromu, kao i o sučeljavanju Frojdovog i Jungovog modela u ovom kontekstu u knjizi Zašto Crno pristaje Elektri (MITIĆ, 2004).
} 
negativan vrednosni predznak, ali strategija čitanja koju je u ranoj fazi mogao da ponudi akademski feminizam bila je u suštini samo obrnuta replika tradicionalne akademske kritike. Kako bi u Eshilovoj tragediji mogla da vidi veličanstvenu apoteozu novog poretka, tradicionalna kritika morala je da previdi svaki nagoveštaj ironije, što je iz perspektive tradicionalne (,muške”) kritike bio interpretativni obrazac koji ima svoje ideološko objašnjenje, mada ne i opravdanje. Ovo zadržavanje identičnog obrasca u pristupu feminističke kritike Geč vidi kao rezultat neshvatljive predrasude, koja svoje poreklo, po njenom mišljenju, ima u stavu francuske feministkinje Elen Siksu [Helene Cixous]. Radi se zapravo o rečima iz čuvenog teksta „Smeh Meduze”, u kome Siksu ispisuje poetski manifest feminizma, pri čemu žena mora da piše ženu, a muškarac muškarca. Ako ove reči istrgnemo iz šireg konteksta dekonstrukcijskog čitanja i shvatimo na doslovan način, postaje jasnije, mada ne i više opravdano, zbog čega je ne samo feministička književna kritika, već i pozorišno izvođenje Orestije u postavci feministički orijentisanih rediteljki ${ }^{7}$, zadržalo gotovo identičan pristup Eshilu koji srećemo u kritičkim prikazima tradicionalne kritike.

Insistiranje na neprikosnovenosti autorove namere, kao vrhunskom parametru semantičke analize književnog teksta, trebalo je da ovako koncipirani autoritet književne kritike još i dodatno sankcioniše. U tom smislu, paradigmatičan je pristup jednog od poznatijih teoretičara antičke drame (KONAHER, 1987) koji, budući da piše sa kraja osamdesetih i iz sada već u dobroj meri poljuljane pozicije tradicionalne akademske kritike, ne može da ignoriše činjenicu kako je Eshila moguće tumačiti i sasvim drugačije u odnosu na tradicionalni kritički model, ali ipak pronalazi način da dovede u sumnju validnost drugačije koncipirane interpretacije. Konaher uzima u obzir činjenicu da ove drugačije interpretacije Eshila postoje i da ih treba uvažiti, ali ovaj naizgled tolerantan stav ima prevashodno za cilj da na čitaoca ostvari utisak kritičke slobode izbora. Ovaj utisak, međutim, skoro u potpunosti nestaje onog trenutka kada navodno objektivni kritičar nazove ova drugačija tumačenja, koja beleže mogućnost odstupanja od tradicionalnog modela, imputiranjem Eshilu sopstvenih želja o tome šta bi tekst trebalo da znači. Kritičar se opredeljuje, na deklarativnom planu sasvim nepristrasno, za onu interpretaciju koja u Apolonovoj odbrani oca kao jedinog istinskog roditelja ne vidi nikakvu ironiju, budući da takva interpretacija, tvrdi Konaher, najbolje izražava šta je Eshil „,hteo da kaže”, a „sve su indicije”, tvrdi ovaj kritičar, „da je Atenin sud i, posebno, status quo (muške superiornosti) koji ovaj sud reprezentuje Eshil smatrao savršeno zadovoljavajućim" (KONAHER 1987: 208).

\footnotetext{
${ }^{7}$ Seli Geč posebno spominje i detaljno, u tom smislu, analizira veoma zapaženo pozorišno izvođenje Orestije u režiji Ariane Mnučkin [Ariane Mnouchkine] i u postavci čuvenog francuskog pozorišta The Théatre du Soleil (čiji je jedan od osnivača upravo pomenuta rediteljka).
} 
Zavedenoj postavkom da „samo žena može da piše ženu”, feminističkoj kritici je, po svemu sudeći, promakao onaj dragoceni detalj koji ovakvim argumentacijama daje jedan sasvim drugačiji ton, a samu poziciju tradicionalne akademske kritike poništava iznutra. Jer čak i kada bi namera autora mogla da bude taj vrhovni kriterijum koji mora presuditi u određivanju značenja književnog teksta, i kada bi kritičarev ili čitaočev zadatak zaista i trebalo da se sastoji u tome da, kao što ironično primećuje Filip Velakot, prizove Eshilov duh i upita ga šta je imao na umu dok je pisao čuvene reči koje izgovara boginja Atena, opet se ne bi moglo izbeći upravo ono što u ovako koncipiranoj argumentaciji ostaje neprepoznato - prisustvo same interpretacije kao odlučujućeg subjektivnog faktora u činu tumačenja. Kada je reč o Orestiji, dva jedina izvora koja nam mogu pomoći da eventualno dokučimo šta je Eshil hteo da kaže jesu, kako ističe Velakot, istorija Helade koja se odnosi na vreme u kome piše Eshil, i koja nam je u velikoj meri dostupna, i sam tekst Orestije. Ali oba ova izvora neminovno podležu činu interpretacije - uplitanju, dakle, onog faktora od koga je patrijarhalna institucija čitanja oduvek najviše zazirala zato što čin vrednosnog određivanja nepovratno ruši temelje čitavoj građevini. Patrijarhalna kritika bila je već logikom svoje namene prinuđena da insistira na naučnom statusu kritičke aktivnosti budući da bi priznavanje sopstvenog vrednosnog opredeljenja - kao neizbežnog polazišta svake interpretacije - povuklo za sobom i demistifikaciju ideološke dimenzije sopstvene pozicije. Ovakav čin bi, naravno, automatski stvorio mogućnost izbora drugačije pozicije kao drugačijeg ideološkog i vrednosnog određenja, a pritom se radi upravo o mogućnosti koja jedina može da dovede do revizije o kakvoj, između ostalih, govori i Adrijen Rič.

Kada je u pitanju Eshil i akademska kritika na engleskom govornom području, ovakav početak, pored Filipa Velakota, i pomenutog teksta Seli Geč, predstavlja i obimna studija britanskog kritičara i filologa Sajmona Goldhila [Simon Goldhill] iz 1984. godine. Budući da piše iz pozicije poststrukturalizma, Goldhil u uvodnom poglavlju svoje knjige daje dragocen osvrt na sam pojam ,čitanja” i prirodu značenja u književnosti, a značaj ovakve studije nesumnjivo je u tome što antičku dramu, i posebno Eshila, koji su neshvatljivo dugo ostali u domenu inače prevaziđenih shvatanja tradicionalne književne teorije, po prvi put dovodi u kontekst poststrukturalne hermeneutike čitanja. U veoma efektno sprovedenom i intrigantnom spoju moderne dekonstrukcije i klasične filološke analize, antička drama postaje prepoznata kao „otvoreno delo" na koje se, sa istom onom prirodnošću sa kojom to činimo kada su u pitanju književni tekstovi savremenih autora, mogu primeniti koncepti tekstualnosti, označavanja i pluralnosti značenja. Sledeći Barta, Goldhil pokazuje kako se i na primeru Orestije možemo uveriti da je značenje uvek čin svođenja ili osmišljavanja tekstualnosti, i kao takvo uvek proces ukrštanja dva 
osnovna diskursa - diskursa teksta sa diskursom čitaoca. Kroz jednu veoma minuciozno izvedenu filološku analizu, on pokazuje kako se teza da „nema nevinih čitanja" podjednako odnosi i na tekstove klasičnih autora. Budući da se tekst upravo svojom tekstualnošću opire logici interpretacije, svako čitanje podrazumeva ne samo neizbežni upliv subjektivnog i ideološkog, već i svojevrsno svođenje nesvodivog - delimično ,ukidanje” semantičke pluralnosti kao osnovne dimenzije u kojoj postoji i deluje umetnički tekst.

Kao dosledni dekonstrukcionista, Goldhil, očekivano, prekida svoju analizu Orestije upravo na mestu na kome bi čin vrednosnog određenja zaista mogao da otpočne. Njegova studija o Eshilu završava se tako što sam autor ne podleže ,iskušenju” da izloži sopstvenu interpretaciju - kao sopstveno čitanje Orestije. Pa ipak, to što sam autor u želji da naučni status svoje analize ne naruši prisustvom ličnog i subjektivnog, odustaje od interpretacije, kao od sopstvenog vrednosnog opredeljenja, ne umanjuje značaj ove izvanredne studije. A značaj je upravo u identifikaciji mesta na kome je u feminističkoj kritici proklamovani zadatak revizije jedino mogao i trebalo da otpočne. Jer tek onda kada se kritici oduzme pravo zaklanjanja iza neprikosnovenih autoriteta, kao garanata značenja, i kada je kritičar primoran da obelodani i ukaže na udeo lične i ideološke dimenzije u procesu tumačenja književnog značenja, čin interpretacije počinje da funkcioniše kao delatni čin određivanja naspram kulture. Odricanjem od patrijarhalnih ideala moći i kontrole, on se iznutra oslobađa taloga represivnog ideološkog nasleđa, prerasta u društveni angažman i postaje značajan putokaz u procesu osvešćivanja onih sadržaja psihe koji su kroz proces potiskivanja proizveli pogubnu destruktivnost zapadne kulture.

\section{Zaključak}

Čin opstanka koji spominje američka pesnikinja Adrijen Rič povezan je sa uviđanjem kritičkog potencijala umetnosti, ali i sa prihvatanjem ideološkog određivanja, kao neizbežnog i dragocenog u činu interpretacije. Sučeljavanje suprotstavljenih interpretacija u tom slučaju prestaje da bude poligon za eksponiranje superiornosti, već postaje istinski dragoceno sučeljavanje suprotstavljenih vrednosnih pozicija ne samo u odnosu na tekst, već i u odnosu na kulturu, čije su simboličke predstave na najupečatljiviji način utkane i sačuvane upravo u umetničkim delima. U mitu o Orestu i zločinu nad majkom, prikazuje se u kodiranoj formi da je opravdanje ovog čina i samo došlo kao rezultat prethodnog potiskivanja - boginja Atena mogla je da oslobodi Oresta i oprosti zločin, ali samo zato što je i sama bila predodređena da tako postupi. Njena predodređenost je ostala sakrivena iza onoga što mit nudi kao manifestni sadržaj sopstvene metafore. Duboko ispod površine, ukazuje se strukturni 
mehanizam specifične kulturne matrice koji je pojedina značenja uspostavio kao samorazumljiva, a druga potisnuo i učinio nevidljivim. U slučaju Atene, ova „nevidljivost” odnosi se na samo njeno poreklo koje u sebi već sadrži ranije sprovedenu simboličku represiju. Ubistvo Klitemnestre, drugim rečima, počiva na jednom ranije odigranom činu ubistva koje mitska metafora prikri$\mathrm{va}^{8}$, a čije je postojanje do te mere prebrisano iz onoga što čini sećanje i svest kulture da ga ni sama Atena ne prepoznaje kao deo vlastitog porekla. Iz svega do sada rečenog, jasno je da konačni cilj feminističke dekonstrukcije mora biti u tome da se prepoznaju i rehabilituju svi ovi sadržaji koji su, kroz simboličku i institucionalnu potvrdu patrijarhalnih fantazija, bili odbačeni i potisnuti kako bi dominantni diskurs zadržao status neprikosnovenog zakona.

\section{Citirana literatura}

BOGARD 1972: BOGARD, Travis. Contour in Time - the Plays of Eugene O'Neill. Oxford University Press, 1972.

KONAHER 1987: CONACHER, D.J. Aeschylus: Oresteia - a Literary Commentary. University of Toronto Press, 1987.

DEJČIZ 1961: DAICHES, David. „Mourning Becomes O’Neill”. Encounter XVI, 1961.

DONOVAN 1975: DONOVAN, Josephine. (ed.) Feminist Literary Criticism: Explorations in Theory. The University Press of Kentucky, 1975.

ĐURIĆ 1994: ĐURIĆ, Miloš. Grčke tragedije. U prevodu i sa objašnjenjima Miloša Đurića. Beograd: Srpska književna zadruga, 1994. [orig.] Грчке трагедије, Eсхил. Књ. 1. Милош Ђурић (ур.). Београд: Српска књижевна задруга, 1994.

FLEKSNER 1966: FLEXNER, Eleanor. American Playwrights: 1918-1938. New York: Books for Libraries Press, 1966.

GEC 1994: GOETSCH, Sallie. „Playing Against the Text: Les Atrides and the History of Reading Aeschylus", The Drama Review. Vol. 38, No. 3, 75-95, 1994.

GOLDHIL 1984: GOLDHILL, Simon. Language, Sexuality, Narrative: The Oresteia. Cambridge University Press, 1984.

DŽEJKOBS 2007: JACOBS, Amber. On Matricide: Myth, Psychoanalysis, and the Law of the Mother. Columbia University Press, 2007.

IRIGAREJ 1991: IRIGARAY, Luce. ,The bodily encounter with the mother” u Margaret Whitford (ed.), The Irigaray Reader. Oxford: Blackwell Publishers, 1991.

\footnotetext{
${ }^{8}$ Reč je o simboličkom ubistvu majke koje Lis Irigarej označava kao temelj represivne ideološke matrice patrijarhata, a koje se ovde odnosi na mitsku priču o ubistvu Atenine majke, čije je znanje i moć Zevs prisvojio za sebe, simbolički progutavši trudnu Metis.
} 
MITIĆ 2004: MITIĆ, Petra. Zašto crno pristaje Elektri. Beograd: Narodna knjiga, 2004.

O’NIL 1984: O’NIL, Judžin. Crnina Priliči Elektri. U prevodu Dragoslava Andrića. Beograd: Srpska književna zadruga, 1984. [orig.] О'Нил, Јуџин. Црнина приличи Електри: трилогија. Београд: Српска књижевна задруга, 1984.

VELAKOT 1991: VELLACOTT, Philip. An English Reader's Guide to Aeschylus: Oresteia. Cambridge: Monophron, 1991.

\section{Petra Mitić}

\section{THE ORESTEIA BY AESCHYLUS IN FEMINIST CRTICISM - FROM CONDEMNATION TO SIGNIFICANT REREADING}

The controversy that ensued after the publication of Eugene O'Neill's famous trilogy Mourning Becomes Electra proves how much of a challenge the text of Oresteia still presents for critical theory. The Nobel laureate's desire to offer a contemporary rereading of this capital text of literature was marked by the critics' attempt to enforce the Oedipal pattern of reading - the right measure of what they considered to be the true meaning of his text - as well as by the author's own attempt to show there had been no such intention on his mind when writing his play. O'Neill's endeavour to „defend” his text against what he thought to have been a gross misreading will be taken here as the starting point, the main purpose of this paper being to shed light on the aspects of meaning in Aeschylus that traditional criticism has chosen to ignore. The context of this polemics has also revealed the shortcomings of the orthodox feminist analysis. The irony is shown in the fact that though feminist critics had started with the ideology opposite to the officially supported patriarchal model of interpretation, they actually ended repeating the very same pattern of reading. Instead of offering a significant breakthrough from the domain of traditional hermeneutics, this radical school of criticism thus remained „blind” to all those subversive aspects of meaning in Aeschylus, which critics like Sallie Goetsch and Philip Vellacott rightfully warn about.

Key words: Oresteia, Eugene O'Neill, the patriarchal model of reading, feminist criticism and interpretation, deconstruction and rereading 